\title{
An Ecological Based Multi-Sensory Science Model for Cognitive and Social Development in Early Childhood
}

\author{
Helena $^{1, *}$, Yaswinda $^{1}$ \\ ${ }^{1}$ Department of Early Childhood Education, Faculty of Education, Universitas Negeri Padang, Padang, Indonesia \\ *Email: Helena_amrin03@gmail.com
}

\begin{abstract}
Science learning is important to early childhood so that they can understand the world and the environment around it through a variety of processes that are then known as scientific investigations. Science learning is able to create an engrossing learning atmosphere that is essentially close to the children and they have witnessed daily. Children are expected to be able to solve the problems faced by science learning. Science that covers the context of multisensory by involving the entire sensory tool allows the child to obtain intact information, so as to improve their cognitive development. Social development in early childhood also had to obtain a balanced portion. People need others for survival, early childhood should be directed to be able to form good social relations with people and the environment around them. So anti-social behaviour can be hit. A multisensory ecological-based science learning Model is expected to improve cognitive and social development in early childhood.
\end{abstract}

Keywords: early childhood, multi-sensory-ecological-based science learning model

\section{INTRODUCTION}

Education is an obligatory thing for every child. With education can be gained excellent human resources and full of competence. Early childhood Education (PAUD) has an important role because in this age range is the first foundation of growth and development in children in the beginning. Havu-Nuutinen's opinion in Mirawati \& Nugraha[1] stated that with the concept of science embedded in the child, it is hoped that the child is able to confront and resolve the problem later in the day. Jakman[2] States science is a combination of process skills that can measure the extent to which children are able to learn and what content they learn.

Man is a monodualist creature, the individual beings as well as a social creature. One of the forms of monodualist beings is in fulfilling his daily needs and as a social creature of course humans need another human being in life. Socializing ability plays an important role to help people to complete and fulfill daily needs.

Various gaps or problems in science learning activities where science learning in children can provide a meaningful experience for early childhood such as exploration, exploitation and playing activities, with Objects that are close to the child will be able to encourage the child to be active to ask, fiber can interpret the things in the surrounding environment.
However, it was replaced with a monotonous study that was to relate to the child about the theories of the school magazine or the student's worksheet.

Science learning Media used by teachers in learning activities is less diverse. Children are even often just an audience of demonstration activities conducted by their teachers, this is influenced by the limitations of the media provided by the school or by the teacher himself. It is of course very worrying considering the child's inevitability in the development stage where the child has always had the desire to try, expression, explore and exploit the objects that Around them. So that the cognitive development of children can be obstructed and not developed with maximum.

The social development of the early childhood is not optimal in the mark with the low desire of children to share and socialize with their peers. Interwoven friendships are often fragile and often quarrel for small things. Child fatigue with technology such as gadgets also leads to low social interaction in children. Some of the above issues are interesting for the writer to uncover the "influence of multisensory science-based learning - ecology towards improving cognitive and social development in early childhood".

\section{LITERATURE REVIEW}

Early childhood according to the view of the three philosophers in Santrock[3] based on an understanding of original sin, steadiness, and early kindness. Froebel[4] says 
children develop through openness and like growing plants. Mulyasa[5] early childhood is an individual who is experiencing a very rapid process of growth and development, even said to be a leap of development.

Early childhood is defined by the National Association for the Education of Young Children (NAEYC) is a child aged 0 to 8 years [6]. Samatowa[7] restricting chronically early childhood (early Childhood) is a child that ranges between the ages of 0 and 8 years old. While LAW No. 20 year 2003 says that early childhood is the child who is 0 to 6 years old. According to Suryana[8] It states that early age is the most important and fundamental starting period along the growth range and the development of human life.

The characteristics of early childhood learning are very different, the way they study is different from adults, where early childhood has egocentric nature, active, has a great curiosity, is easily frustrated, like to daydream in carrying out Something that he didn't wanted. There are some characteristics of early childhood that are prominent in relation to learning activities. Sudarna[9] presents some characteristics of early childhood, namely: Unique, egocentric, active and energetic, strong and enthusiastic curiosity of many things, explorative and soulful adventure, spontaneous, happy and rich in fantasy, still easy Frustrating, still less considering doing something, short attention, passionate about learning and learning a lot from experience and increasingly showing interest in friends.

\subsection{Early Childhood Education Concept}

Mulyasa[10] argues, early childhood education is the first and foremost foundation in the personal development of the child, whether related to character, physical abilities, cognitive, language, art, social, emotional, spiritual, selfdiscipline, Self-reliance.

Yulsyofriend[11] Early Childhood Education is an effort aimed at stimulating, guiding, nurturing and providing learning activities that will result in children's abilities and skills. Early childhood education has a very decisive role. Comenius in Morrison[4] said education should begin at an early age because "young plants can be planted, minted, trimmed, and molded". In this age, a variety of growth and development begins and is engaged, such as physiologic, language, motor, cognitive, social and emotional developments.

Dewey in Suryana[12] The role of educators in educating early childhood is: (1), observing children closer and planning a curriculum based on their interests and experiences. (2), do not be afraid to use your knowledge of children and the world to understand the world for children. Based on the explanation above, it is concluded that early childhood education is the basis of personal development of children from birth to age six years relating to character, physical, cognitive, language, art, social, emotional, spiritual, Self-discipline, self-concept, or the benefit of the effort requires parents and teachers to guide, nurture and care so that the child can learn to recognize the surrounding environment, so that the child is ready to enter the next level of education.

\subsection{Objectives of Early Childhood Education}

Early childhood education is not just preparing children to enter elementary school. The actual early childhood education function is to help develop all potential children (physical, language, intellectual/cognitive, emotional, social, moral and religious) and put the foundation toward the development of attitudes, knowledge, skills and power To adapt itself to its environment for further growth and development, in [13].

According to Sujiono[15] the purpose of early childhood education is to develop a variety of potential children since early in preparation for life and can conform to its environment. Direction of education of early childhood according to law No. 20 of year 2003 in Yulsyofriend[11] namely: (1). Physical growth and development (fine and coarse motor coordination); (2). Intelligence (mindset, copyright, emotional intelligence and spiritual intelligence; (3). Social-emotional (Religious attitudes and behaviors, language and communication adapted to the uniqueness and developmental stages of early childhood).

Delfita in Wulandari, Ichsan, \& Romadhon[16] states the purpose of early childhood education is: 1). Provide parenting and mentoring that allows the child to grow and develop according to their age and potential, 2). Identifying Possible irregularities occur, so that if there is deviation can be done early intervention immediately, 3). Provide a diverse and inviting experience for early childhood, allowing them to develop potential in various fields, so they are ready to attend formal education, 4). Build a foundation for the development of the potential learners to become men of faith and fear of the One True God, 5). Develop the potential of spiritual, intellectual, emotional, and social intelligence in the golden Age of educative and fun playing environment.

Based on the opinion of the experts above, it can be concluded that the purpose of early childhood education is to develop all potential children related to cognitive development, language, physical, social, emotional children and other potentials with optimal So they are able to adapt to the surrounding environment which is useful for the child for the next life.

\subsection{Cognitive Development of Early Childhood}

Piaget in Allen \& Marotz[17] cognitive development is a process of interaction that takes place between the child and his or her perception of an object or incident in his ward. Piaget in Santrock[18] suggests cognitive processes in children is a unit of soul and body that can not be separated therefore Piaget is the four basic concepts that become a reference to the occurrence of cognitive itself namely, (1). Schemes, concepts or frameworks that exist in the individual mind to organize and interpret the information, (2).Assimilation, a mental process that occurs when a child enters new knowledge into an existing knowledge, (3).Accommodation, a mental process that occurs when a child adapts to new information, (4). The equator, a 
mechanism proposed by Piaget to explain how the child moves from one stage of thought to the next. This shift occurs when a child has a cognitive conflict or is disequilibrium in his attempts to understand his world. Eventually the child can solve the conflict and gain a balance of thought.

Sudarna[9] cognitive is a process that occurs internally in the central nervous structure at the time the human being thinks. According to Sujiono[15] in his book cognitive is a process of thinking, which is the ability of individuals to connect, assess and consider an incident. Cognitive development illustrates how the child's mind develops and functions so that it can be thought. The process of thinking relates to the level of intelligence that characterizes a person with a variety of interests, especially aimed at ideas and learning spirit.

According to Piaget[15] reasons why the importance of teachers developing cognitive abilities of children are : 1) in order for children to develop their perception based on what he saw, hear and feel, so that the child has a complete understanding and comprehensive, 2) so that the child can train his memory of all events and events that have been experienced, 3) so that the child is able to develop his thoughts in order to connect an event and events that have been experienced, 4) In order for the child to understand the various symbols, 5) so that the child is able to perform reasoning well that occurs through a natural process (spontaneous), as well as events that occur through the scientific process (experimental), 6) in order for the child to solve The question of life he faced so that he would be an individual capable of helping himself.

Mena \& Eyer[19] suggests cognitive development into concern as it relates to skills, memory, language and problem-solving skills. Cognitive development aims to develop children's thinking skills to be able to cultivate their learning, and can find a variety of troubleshooting alternatives. Therefore, the aspect of cognitive development in children should be really well-stimulated, teachers should be able to see the level of cognitive development of each child in his/her own and give proper stimulation anyway.

\subsection{Early Childhood Social Development}

Social development has an important role in life, the better the social value of a person in the environment, the sooner they will be accepted in the social environment. Children need stimulation in many aspects of development is no exception to the aspect of social development. The child will face different background individuals with him, this is where the role of social development is indispensable for the child. So they can be easy to get in and socialize with the environment in which they reside.

Pearson \& Rodgers[17] reveal that social development includes the feeling of a child towards oneself and their relationship with others, this refers to the behavior and response of the child to play and engage and Their proximity to those around him. Many things that affect social development include gender roles, independence, morality, trust and acceptance of the prevailing regulations in the environment.

Henniger[20] social studies help children understand relationship between people and environmental factors that influence their lives. Social sciences can help children in adapting to their environment. According to Hurlock[21] social development is the acquisition of the ability to behave in accordance with social demands. The development of child behaviour to adapt to the prevailing rules in the community is a form of social development.

Surna \& Pandeirot[22] reveal the process of social development is a task that children must undergo in the developmental process that is dealing with different values and morals with others, faced with the thoughts and opinions of people In social and cultural environments.

Social development is the behavior of the child's response to be able to adapt to other people in the school environment, family also peers and obey the rules of values and norms that apply in the environment, the extent of the social world of children As you grow older and enter a secondary school, children's activities will also be more diverse, therefore children must learn to interact well.

\subsection{Science Studies in Kindergarten}

Learning is a process that will be traversed by every human being in the level of life in different portions that correspond to the abilities and development of each individual. Morrison[4] suggests children's age of kindergarten is age five to six. The Hadith[7] states childhood is also known as preschool age or kindergarten age with a range of age between 3 to 6 years. It can then be concluded that the child's age is around 2 to 6 years old. Learning activities in kindergartens are designed to form behaviors and develop the basic capabilities of kindergarten age children.

Science learning must be adapted to the developmental stages of the child [7]. Science learning in kindergartens gives children the opportunity to observe the surrounding environment while still paying attention to the growth and development of cognition, physical, language, social, emotional children. Even the development of self-reliance, discipline, self-concept, art, moral and religious values can also be achieved in an integrated.

The importance of science learning in kindergarten according to Morrison[4] is as follows:

- Science is the ideal means to develop children's minds to inquire about the natural world.

- Implementing the National Science Education Standards can help our students enter into a science-literate society.

- When children explore science, they have spoken and written languages for the expression of science and learn to read in a new context. 
- Science teaches children to appreciate the diversity of life and its inter-connectory.

- When children learn about nature, they respect and care for our planet and its natural resources.

- Learn scientific methods teach children to look to themselves as scientists.

- Lessons in an interesting science field can encourage lasting love towards that subject.

Based on the explanation above we can conclude that the science lessons in kindergarten should be in accordance with the stages of children's development, important science in the kindergarten to be able to improve and develop the skills and attitudes Science in children. The application must also be implemented and controlled and use the appropriate methods so that the objectives to be achieved can be realized. Teachers play an important role to improve this ability by choosing the right model and strategy of learning so that science is interesting for children.

\subsection{Multi-Sensory-Ecological-Based Science Learning (PSB MU-GI)}

Science learning must be packed with interest so the child is more enthusiastic and passionate about learning. Interesting learning will also cause an impression and encourage children to love the learning. Basically science learning is very interesting for children so that teachers will be easier to transfer the knowledge that will be delivered and should be absorbed well by the child.

Science is defined as a way to try to discover the nature of all things, attitudes, and skills that allow individuals to solve the problems they face in their daily lives, Rosalind and Karen in the [23]. The content of science for early children is a discover concepts, scientific reasoning, the nature of science, and doing science [23].

Yaswinda[2], sensory is the process of detecting the existence of the stimulus from the outer environment through the sensory (exsoreseptor). It can be said that children use all the senses in search of information relating to the learning they are facing.

The multisensory according to Armstrong and Lazear in DePorter, Reardon, \& Nourine[24] is a learning activity that is in the stacking while utilizing three or four multidisciplinary students such as visual, Auditorial and kinaesthetic. Fiani, S.P, \& Diana[25], a multisensory approach emphasizes teaching through visual, auditory, kinaesthetic and tactile principles. Fox and Schirrmacher[2] However, for most of its history, the term "multisensory" had been synonymous with the term "bimodal" (describing a neuron that can be activated by the independent presentation of stimuli from more than one modality.

McIntyre[6] reveals that The role of experience in science is primary - science cannot be done without touching, tasting, smelling, pushing, pulling, rotating, mixing, comparing and so on. Science activities are not possible without the use of many senses. It can be concluded that multi sensory is a learning activity that involves all the tools of the senses so that the experience is intact and thorough.

Ecology comes from the Greek oikos meaning home or living place and logos which means science. Literally ecology is the science that learns the reciprocal relationship between organisms and their environment, [26].

Ecology according to Smith \& Smith[2], ecology is the study of relationships between organisms and their environment, including the physical and chemical and biological components or the surrounding living beings. This relationship includes interactions with the physical world as well as with the members and the same or different species. Jackman[27] ecology is the study of living thing in relation to their environment and to one another.

As for the characteristics of multisensory-ecology based science learning according to Yaswinda \& Ismet[28] is exploration.

\subsubsection{Ecology}

A series of scientific learning processes through the invention of a science content that includes biology (human, plant, and animal) its function and place of life, physics (objects and energy), the Universe (sky, changes in the weather, rocks, sun, Moon and planets) Environment (preserving the environment).

\subsubsection{Multi-Sensory}

Providing experience of many variations/media learning involving various stimulation of senses including, hearing, vision, touch, taster, and smell in science learning so that the child is expected to get information and act of many learning resources that support sensory stimulation.

\subsubsection{Variations of learning media}

The absolute media variation in this model because the multi-sensory based, the media used in the form of equipment that supports the stimulation of the senses, among others, (1).Equipment and materials that encourage visual exploration (binoculars, magnifying glass, VCD, pictorial Storybook, paints and brushes), (2).Auditory equipment, which encourages active hearing (CD player, VCD, speaker), (3).Tools and materials that support the exploration of Flavour Development, (4).Tools and materials that support the exploration of the Smell senses, (5).Tools and materials that encourage tactile developments (tactile/tactile). 


\subsubsection{Theme Opening with Project Learning}

Initial interaction with the environment will bring children to a new perspective on how the Earth is managed and helps the child to expand knowledge so that the awareness and interest in science and environmental sustainability arise.

The earth needs to be kept in its sustainability, therefore early childhood should be aware of the importance of keeping the earth by doing activities that can reduce Earth damage such as the use of residual goods, natural materials, and used materials.

The learning principle of multi-sensory-ecological based science learning model according to Yaswinda[23] is:

\subsubsection{Child-centered Learning}

The needs of children dominate the needs of teachers, subschools, school administrators or community groups. It aims to develop the ability of children naturally in accordance with its development actions, make children free and safe psychologically, improve the cooperation and caring of schools, families and communities, emphasizing the azas of openness To support children's education and to complement the needs that support children's development optimally.

\subsubsection{Integrated Learning}

Integrated learning is a form of learning that combines authentic events through a selection of themes that encourage the curiosity of children to solve problems through an exploratory approach.

\subsubsection{Learning through Play}

Playing is an important activity for children to develop developmental aspects such as social, muscles and their mentality. To get to know the surrounding world using the five senses. There are four classifications in the multisensory-ecological learning science, (a). Free Play is a play activity where kids can choose how to use the ingredients in play, (b). Play with guided is before playing guided children choose certain materials to find certain concepts, (c). Play directed and role playing, play directed is a play where teachers instruct the children to complete a specific task, (d). Role-playing, role-playing consists of two types of micro-role play, the child plays a role/figure through small objects like play car small size. Role-playing macro, the child plays a role/figure through objects that are near the size of actual or large objects such as, playing the father/Mother RT in a clean environment activities.
Project Learning is a lesson that applies a learning ideology that centers on children with a way of giving children a learning experience to solve daily problems or issues. Project delivery can be initiated with exploration activities and then continue to project methods. Can be done individually or in groups.

\subsubsection{Simultaneous Assessment}

In the study of multi-based science sensory-ecology simultaneous assessment has the characteristics of: (a). Continuous, carried out in a planned, gradual and persistent manner, (b). Process-oriented and objectives, (c). Thorough, assessment The child's process or outcome, (a). Objective, providing correct information about child growth and development.

\section{C CLUSION}

Science studies given in kindergartens should pay attention to all aspects of child development, especially the cognitive and social development of children. In addition, the treatment and comfortable feeling of the child in learning should also always be the concern of teachers. Multi Sensory is the involvement of all sensory instruments in learning which include, sense of sight, smell, tasting, taste and hearing. While ecology is an activity that invites children to be closer to the nature and environment around them. Teachers should use appropriate methods in learning. With the method of learning science-based multi sensoryecological things above will be realized and teachers can also easily use it. Because this method of multi-sensorybased science learning has five characteristics namely 1), Exploration, 2). Multi sensory, 3). Learning media variations, 4). Interactions, 5). Activity reduces earth damage. This paper is expected to be useful and to help teachers develop science learning. So that interesting science learning can be created, as well as increased cognitive and social development in early childhood children will also be realized.

\section{ACKNOWLEDGMENT}

In this moment I would like to thanks Mrs. Dr. Yaswinda, M.Pd.

\section{REFERENCES}

[1] Mirawati and R. Nugraha, "Meningkatkan Keterampilan Proses Sains Anak Usia Dini Melalui Aktivitas Berkebun," Early Child. J. Pendidik., vol. 1, no. 1, pp. 1-15, 2017.

[2] Yaswinda, "Development of a Procedural Model of Science Based on Multisensory-Ecology for Early 
Kognitif Anak Usia Dini Melalui Media Bermain Memancing," J. Pendidik. Dan Pemberdaya. Masy., vol. 3, no. 1, pp. 97-108, 2016.

[3] J. W. Santrock, Life-Span Development: Perkembangan Masa Hidup, Kelima. Jakarta: Erlangga, 2002.

[4] G. S. Morrison, Dasar-dasar Pendidikan Anak Usia Dini (PAUD), 5th ed. Jakarta: Indeks, 2012.

[5] Mulyasa, Manajemen PAUD. Bandung: PT. Remaja Rosdakarya Offset, 2012.

[6] J. A. Brewer, Introduction to Early Chilhood Education: Preschool Through Primary Grades. USA: Pearson Education, Inc, 2007.

[7] U. Samatowa, Metodologi Pembelajaran Sains untuk Pendidikan Anak Usia Dini. Tangerang: TSmart, 2018.

[8] D. Suryana, Pendidikan Anak Usia Dini (Teori dan Praktek). Padang: UNP Press, 2013.

[9] Sudarna, PAUD Pendidikan Anak Usia Dini Berkarakter. Yogyakarta: Solusi Distribusi, 2014.

[10] E. Mulyasa, Menejemen Pendidikan Karakter. Jakarta: Bumi Aksara, 2012.

[11] Yulsyofriend, Permainan Membaca dan Menulis Anak Usia Dini. Padang: Sukabina Press, 2013.

[12] D. Suryana, Pendidikan Anak Usia Dini Stimulasi dan Aspek Perkembangan Anak. Jakarta: Prenadamedia Group, 2018.

[13] A. Yus, Penilaian Perkembangan Belajar Anak Taman Kanak-Kanak. Jakarta: Kencana Pranada Media Group, 2012.

[14] Sujiono and Yuliani Nurani, Konsep Dasar Pendidikan Anak Usia Dini. Jakarta: PT Indeks, 2012.

[15] N. Y. Sujiono, Konsep Dasar Pendidikan Anak Usia Dini. Jakarta: Indeks, 2009.

[16] R. Wulandari, B. Ichsan, and Y. A. Romadhon, "Perbedaan Perkembangan Sosial Anak Usia 3-6 Tahun dengan Pendidikan Usia Dini dan Tanpa Pendidikan Usia Dini di Kecamatan Peterongan jombang," Blomedika, vol. 8 , no. 1, pp. 47-53, 2016.

[17] K. E. Allen and L. R. Marotz, Profil Perkembangan Anak: Pra Kelahiran hingga Usia 12 Tahun. Jakarta: PT. Indeks, 2010.

[18] J. W. Santrock, Psikologi Pendidikan. Jakarta: Salemba Humanika, 2014.

[19] W. Retnaningrum, "Peningkatan Perkembangan
[20] M. L. Henniger, Teaching Young Children An Intruduction. USA: Pearson Education Inc, 2013.

[21] E. B. Hurlock, Perkembangan Anak Jilid 1, 6th ed. Jakarta: Erlangga, 2013.

[22] I. N. Surna and O. D. Pandeirot, Psikologi Pendidikan 1. Jakarta: Erlangga, 2014.

[23] Yaswinda, "Science Learning Model Based on Multisensory-Ecology in Early Childhood Education : A Conceptual Model," Adv. Soc. Sci. Educ. Humanit. Res., vol. 58, pp. 463-469, 2017.

[24] B. DePorter, M. Reardon, and S. S. Nourine, Quantum Teaching. Boston: Allyn and Bacon, 2000.

[25] E. A. Fiani, Y. K. S.P, and Diana, "Pengaruh Pendekatan Multisensori Terhadap Kecerdasan LogikaMatematika pada Anak Kelompok A di Taman KanakKanak Kabupaten Kendal,” J. Early Child. Educ. Pap., vol. 1, no. 1, pp. 1-8, 2012.

[26] A. Muhtadi, Diktat Praktikum: Ekologi Perairan Bandung: IPB Press, 2014.

[27] H. L. Jackman, Early Education Curiculum A Child's Connection to the World. Belmont: Wadsworth Cengage Learning, 2012.

[28] Yaswinda and S. Ismet, "Pelaksanaan Model Pembelajaran Sains Berbasis Multisensori-Ekologi di Taman Kanak-Kanak Aisyiyah 6 Kota Padang," Pedagog. J. Ilmu Pendidik., vol. 17, no. 2, pp. 85-92, 2017. 